\title{
Tax Debt Individual Customers in the Russian Federation
}

Salmina S.V.

Kazan Federal University, Institute of Management, Economics and Finance, Kazan, 420008, Russia

Galimardanova Y.M.

Kazan Federal University, Institute of Management, Economics and Finance, Kazan, 420008, Russia

Khafizova A.R.

Kazan Federal University, Institute of Management, Economics and Finance, Kazan, 420008, Russia Email address: svetasv21@yandex.ru

\section{Doi:10.5901/mjss.2014.v5n24p412}

\section{Abstract}

This article is devoted to topical issues of taxation of individuals and the resulting tax liabilities. Managing tax debt is of great importance as the macroeconomic conditions for the transition to sustainable development and improve competitiveness. In our opinion, the management of tax arrears - it's not only the performance of the tax authorities of their duties to collect the debt, but also the formation of the system of economic relations that arise between the state (local government), business entities and individuals regarding the payment of fees. Relevance of the topic is due to increased tax liabilities of individuals in the Russian Federation, as a result, it is necessary to find the optimal tax instruments of debt management.

Keywords: tax; taxation; individuals; tax arrears; management of tax arrears.

\section{Introduction}

One of the mechanisms of influence on the national economy and the formation of the financial resources of the state is the tax system and collection of taxes and fees characterizes its effectiveness. However, continued non-payment reduce the effectiveness of tax relations and limit the government's ability to finance investment and social projects. In addition, the study of the tax debt is necessary to bear in mind the level of confidence in the government and the taxpayers' willingness to pay their taxes. Trust contributes to a sense of goodwill among people, strengthen democracy, and reduces the transaction costs of economic exchange. [3]

Timeliness and completeness of tax revenue is the key to the efficient functioning of the economy of the state. It should be noted that the fight against manifestations of tax evasion is one of the most pressing topics of debate and controversy in the world community. [8] Also, before you go directly to the concept of the tax debt, we would like to note that the issue of taxes is necessary to consider a combination of factors that go beyond their own interests and which have as the main foundation of some aspects of social norms, morality, altruism, justice. [1] The concept of the tax debt has been studied by Mr. Treisman D. in article "Fiscal pathologies and federal politics: Understanding tax arrears in Russia's regions". [11]

The tax debt is the important indicator of the successful tax revenue mobilization through the tax system of the country. The magnitude and rate of change of the tax debt is largely due to the influence of various factors. However, the legislative definition of "tax debt" in the Tax Code of the Russian Federation doesn't exist. There are regulations on issues of collection of tax arrears, tax refund, tax liability, however, the legislative definition of "tax debt" can not be found.

\section{Theory}

The concept of "debt" is defined by the presence of debt and outstanding liabilities (explanatory dictionary S. I. Ozhegov. Encyclopedic Dictionary of Economics and Law defines "debt" as the amount of debt. Debt is the final result of the obligated person, caused by the delay in performing duties or his incomplete performance. Tax debt is the final result of unlawful actions (inaction) of the obligated person, caused by the delay in the implementation of tax obligations, or its 
incomplete execution. Before considering the direct tax liabilities of individuals, it is necessary to define a specified category. Individuals are participants of tax relations. In accordance with Article 11 of the Tax Code, individuals are citizens of the Russian Federation, foreign citizens and stateless persons. An individual is a person as a subject of rights (the bearer of rights and obligations). An individual has a legal capacity in the Russian legislation. An individual acquires the legal capacity at birth and ceases at the moment of death, and the full capacity of an individual acquires at the age of 18. In general, a person can have different legal statuses, sometimes several at once, such as a stateless person, a citizen, a foreigner, an individual entrepreneur, the founder of the legal entity.

We can conclude that the tax liabilities of individuals are the total amount of outstanding obligations to pay statutory taxes and fees assessed penalties for late payment of taxes and fees, and penalties for violation of tax legislation, expressed in the form of money by the citizens of the Russian Federation, foreign citizens and persons without citizenship.

Crokidakis N. consider that the agents (individuals) may be in three different states, namely honest tax payers, tax evaders and undecided, that are individuals in an intermediate class among honest and evaders. [5]

The following types of tax debts of individuals represented in the Figure 1.

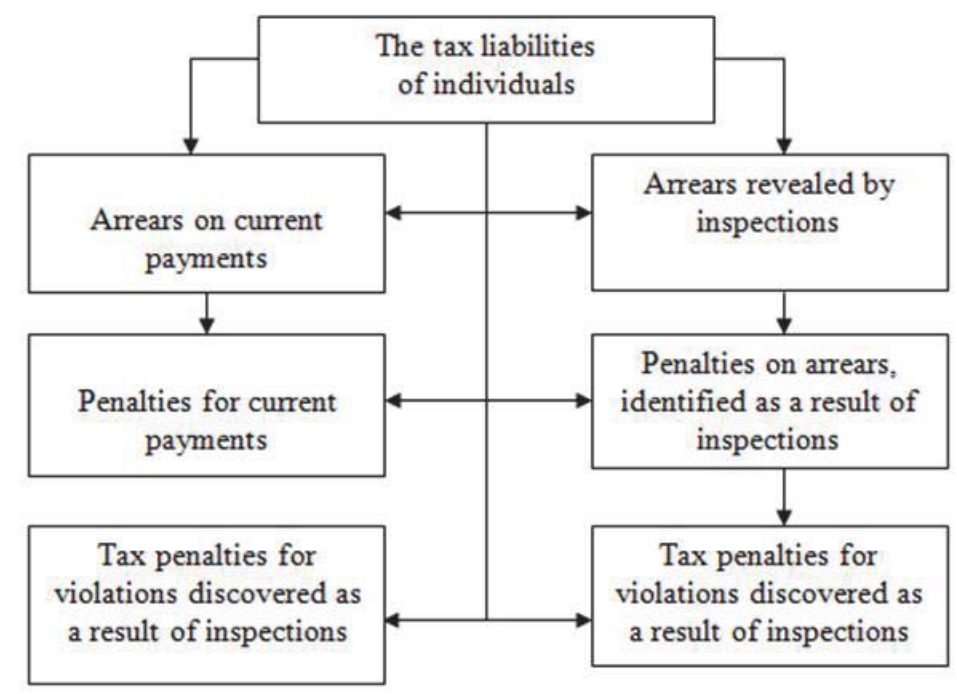

Fig. 1. Types of tax debts of individuals

As of September 1, 2014 the tax liabilities of individuals in the Russian Federation is 96 bln rubles, which is 12\% of the total arrears of taxes and levies, according to the Federal Tax Service of the Russian Federation. As of July 1, 2014 the tax liabilities of individuals in the Republic of Tatarstan is $815 \mathrm{mln}$., which is $10 \%$ of the total arrears of taxes and levies, according to the Office of the Federal Tax Service of Russia in the Republic of Tatarstan. The role of taxes on individuals in the formation of the consolidated revenues rather insignificant, since the payment of taxes on individuals is approximately $7-8 \%$ of the consolidated budget of the Russian Federation. However, the formation of the local budget tax receipts from individuals are the main element in the formation of budget revenues. In addition, administration of taxes on individuals should be given a leading role as the category of individuals is the most numerous category of taxpayers and the further development of tax administration can achieve a significant increase in income from the category of taxes on individuals.

In the article the author Bierbrauer F.J. pointed out that the main result will depend on the provision of public goods, which is associated with the redistribution of the tax system. [2] It should be noted that in the world there is an experience of the United States, where the average tax shall be distributed, the properties of the joint distributions paid taxes and revenues, and explores the impact of taxes on the marital status and number of children. [7] In identifying the causes of the tax debt should be kept in mind the implications of ethical behaviour on the effect of a redistributive taxtransfer system. In choosing their labour supplies, individuals take into account whether their tax liabilities correspond to what they view as ethically acceptable. If tax liabilities are viewed as ethically acceptable, a taxpayer behaves ethically, does not distort her behaviour, and chooses to work as if she were not taxed. [4] 


\section{Results}

In world practice developed a two-period dynamic model of individual choice, considering an individual that has been already audited and detected as tax evader, who knows that Tax Authorities are looking for her to cash the due amount. [6] And there are three hypotheses about the nature of federal tax arrears in Russia in the second half of the 1990s are tested empirically. Tax arrears can be a result of: 1) liquidity problems in firms, 2) redistributive subsidies of the federal government, or 3) regional political resistance to federal tax collectors. [9]

We, in its turn, to analyze and identify the dynamics of the ratio of debt reduction of individuals to total debt and tax revenues give statistics for the Republic of Tatarstan for each analyzed year from 2009 to 2012. in Table 1.

Table 1. Indicators of changes in the levels regulated by the tax debts of individuals

\begin{tabular}{|l|c|c|c|c|}
\hline Indicators & 2009 & 2010 & 2011 & 2012 \\
\hline $\begin{array}{l}\text { The total amount of tax revenue individuals in the consolidated budget of the Russian } \\
\text { Federation, thous. rubles }\end{array}$ & 5043748 & 5880683 & 6888900 & 7879554 \\
\hline The total debt of individuals, thous. rubles & 1225312 & 1146457 & 1099919 & 1374641 \\
\hline Regulated debts of individuals, thous. rubles & 643323 & 636523 & 437645 & 557286 \\
\hline Debt forgiveness of individuals, thous. rubles & 487 & 1346 & 1531 & 10000 \\
\hline Efficiency level of the decommissioned and settled the debt in relation to total debt,\% & 53 & 56 & 40 & 41 \\
\hline The effectiveness of regulated tax debt in relation to the tax revenues for the year,\% & 13 & 11 & 6 & 7 \\
\hline
\end{tabular}

The effectiveness of reducing debt (decommissioned and regulated) in relation to the total debt at the beginning of the year is a general indicator that allows you to determine the level of debt reduction and includes the results of the settlement of tax liabilities in relation to the level of the total aggregate debt. It is calculated by the following formula 1 :

$(\mathrm{Uz}+\mathrm{Sp}) / \mathrm{Obz} * 100=\mathrm{Rez} 1$

where $\mathrm{Uz}$ - regulated debts of individuals;

$\mathrm{Sp}$ - cancel the debt uncollectible;

Obz - the total combined debt at beginning of year;

Rez1 - effectiveness of reducing debt.

The highest rate in the Republic of Tatarstan in 2010 years- 56\%, in 2009 performance indicator was 53\%, in 2011 and 2012 level of efficiency decreased and amounted by $40 \%$ and $41 \%$ respectively. The result of this summary indicator will be effective if the rate of the reporting period is higher than in the previous period, that is, the more accrued according to the results of tax audit, the more additional accrual amounts shall be settled through foreclosure, offsetting due to overpayment or written off due to the impossibility of recovery. General indicator is the effectiveness of regulated tax debt in relation to the tax revenues for the year. It allows us to estimate the extent of influence of the tax debt resolution mechanism to increase tax revenues to the budget system. Indicator in relation to the tax revenues can be found using the following formula 2:

$\mathrm{Uz} / \mathrm{NalP} * 100=\mathrm{Rez} 2$

where $\mathrm{Uz}$ - regulated debts of individuals;

NalP - the total amount of tax revenue for the year individuals;

Rez2 - improving the efficiency of tax revenues.

General indicator is the effectiveness of regulated tax debt in relation to the tax revenues in the period of 20092012. It determines the decrease in the efficiency of settled tax debt - a decline from $13 \%$ to $7 \%$. Therefore, in relation to the tax revenue the settled debt is reduced. Efficiency summary measure Rez2 is also determined, as an indicator of Rez1 compared to the same period of the previous period.

In the research Meshkov R. A. defined target criterion "debt credited "repaid and debt tax debt to the tax revenues to the budget system." According to the author, the ratio of the selected indicators selected is not successful because the written-off debt is a debt to be uncollectible, cannot be compared with the tax revenues.

Dynamics of two general indicators is the criteria. Its achievement and exceedance can be used in the comprehensive analysis of the tax authorities. The annual increase in the size of additionally accrued amounts for taxes, interest and penalties increase the total tax debts of individuals. These amounts take precedence over the value of the consolidated tax revenue, which includes recover the debt and debt relief, deemed to be uncollectible. Results of general indicators for the reporting period reflect the efficiency of the tax authorities, and should be compared with the corresponding previous period. Evaluating the effectiveness of reducing the tax debts of individuals allows you to monitor 
system additionally charged and collected sums. Meshkov R.A. proposed settlement criterion composite indicator for objective assessment and adjustment fund bonuses of tax inspections. Under the bonus payment is considered payment of sums of money to government employees over the basic salary in the form of material incentives for the results achieved in the tax regulations. In practice, the tax authorities criterion composite indicator to establish the relationship of particular indicators amounts recovered and amounts written off in relation to the total tax debts of individuals. The fouryear period analysis in the Republic of Tatarstan has shown that the income tax payments due to the implementation of the voluntary-declarative, notification, warning, and forced forms of interim increases annually with relation to debt forgiveness. Evaluation of the composite indicator can be presented in the form of a four-promotion system, shown in Table 2.

Table 2. The rating is a summary measure of the tax debts of individuals

\begin{tabular}{|c|c|}
\hline Condition & Point \\
\hline If $U z / O b z \geq S p / O b z ; A W G \leq 0$ & 4 \\
\hline If $U z / O b z \geq S p / O b z ; A W G>0$ & 3 \\
\hline If $\mathrm{Uz} / \mathrm{Obz}<\mathrm{Sp} / \mathrm{Obz} ; \mathrm{AWG} \leq 0$ & 2 \\
\hline If $\mathrm{Uz} / \mathrm{Obz}<\mathrm{Sp} / \mathrm{Obz} ; \mathrm{AWG}>0$ & 1 \\
\hline
\end{tabular}

where $\mathrm{Uz}$ - regulated debts of individuals;

$\mathrm{Sp}$ - cancel the debt uncollectible;

Obz - the total combined debt at beginning of year;

AWG - comparison of tax losses from non-payment of debts to the budget with the same previous period, that is, changes in one year.

Evaluating the effectiveness of reducing the tax debt is carried out on a four- point system and calculated as the maximum value of the above criteria to the total number of criteria:

1 point - inefficient;

2 and 3 points -average efficient ;

4 points - highly efficient.

Four-point system promotion proved the opportunity to assess the activities of the tax inspection starting with the desk and on-site inspections and ending the use of the full range of measures of tax debt settlement individuals. Full and complex activities of the tax inspection in conjunction with the tax control and tax regulations determined by highperformance score.

Summary criterion will solve the problem of reducing the tax debt exactly on the enforcement proceedings, repayment under deferral of installments, and in the application of preventive, security forms, and not on the writing off debt. Tax authorities should implement the principle of the effectiveness of the settlement of tax arrears. This principle will take steps to resolving unpaid taxes aimed at increasing tax revenues and reducing the tax debt. Effectiveness of the system for recovery of taxes and fees means minimizing the applied methods of settlement of unpaid taxes and maximize their positive effect. Divergent factors influence on the size and dynamics of the analyzed parameters including pendulum migration and their tax potential, the degree of corporate enterprises operating in the region, the level of tax compliance of taxpayers, the content of the regional budget policy in terms of managing debt repayment. The algorithm for calculating general indicators and composite criterion for activities aimed at reducing the tax debt to total debt and in relation to tax revenues, will be easy to apply as to that of other regions as well as to Russia's total indicators.

\section{Conclusions}

On the basis of the study of theoretical issues and practical aspects of the tax debts of individuals, we came to the conclusion that the tax payable including should be analyzed in order to study a tipping point when the investment is replaced by reinvestment. [10] On the basis of the study a four- point system evaluating the effectiveness of reducing the tax debt will have the greatest value from the point of estimating the higher tax authority performance additionally charged amounts subordinate tax authorities.

An example of such an evaluation can be generalized indicators and a combined criterion of reducing the tax debt. This determines the location or position of each region or tax inspection used a rating scale. The proposed method provides a comprehensive assessment of the territorial divisions of the Federal Tax Service, which allows for a comparative analysis between the subjects of the Russian Federation, as well as within the subject, and to identify the 
causes of such indicators to identify specific activities for the next reporting period, in order to increase the effectiveness of the settlement and to reduce tax liabilities.

\section{References}

Alm, J. Does an uncertain tax system encourage "aggressive tax planning"? // Economic Analysis and Policy 44 (1). - 2014. - pp.30-38.

Bierbrauer, F.J. Optimal tax and expenditure policy with aggregate uncertainty // American Economic Journal: Microeconomics Volume 6. - Issue 1 D. - 2014. - pp.205-257.

Birskyte, L. The impact of trust in government on tax paying behavior of nonfarm sole proprietors // Analele Stiintifice ale Universitatii Al I Cuza din lasi - Sectiunea Stiinte Economice Volume 61. - Issue 1. - 2014. - pp. 1-15.

Boadway, R., Marceau, N., Mongrain, S. Redistributive taxation under ethical behavior // Scandinavian Journal of Economics Volume 109. - Issue 3. - September 2007. pp.505-529.

Crokidakis, N. A three - state kinetic agent - based model to analyze tax evasion dynamics // Physica A: Statistical Mechanies and its Applications 414. - 2014. - pp.321-328.

Galmarini, U., Pellegrino, S., Piacenza, M., Turati, G. The runaway taxpayer or: Is prior tax notice effective against scofflaws? /I International Tax and Public Finance Volume 21 - Issue 3. - June 2014. - pp.468-497.

Guner, N. Kaygusuz, R. Ventura, G. Income taxation of U.S. households: Facts and parametric estimates // Review of Economic Dynamics - 2014. - Article in Press.

Kaldiyarov, D.A., Burnasheva, V.R., Kaldiyarov, A.D. Tax evasion and its influence on development of the economy of Republic of Kazakhstan // Life Science Journal 11 (SPEC.ISSUE 5), 19. - 2014. - pp.95-103.

Ponomareva, M., Zhuravskaya, E. Federal tax arrears in Russia: Liquidity problems, federal redistribution or regional resistance? // Economics of Transition Volume 12. - Issue 3. - 2004. - pp.373-398.

Smith, N., Duncan, B., Reid, L. From disinvestment to reinvestment: tax arrears and turning points in the East Village // Housing Studies Volume 4. - Issue 4. - 1989. - pp.238-252.

Treisman, D. Fiscal pathologies and federal politics: Understanding tax arrears in Russia's regions // World Bank Technical Paper. Issue 539. - 2003. - pp.49-67. 